UNITED STATES DEPARTMENT OF THE INTERIOR

Harold L. Ickes, Secretary

GEOLOGICAL SURVEY

W. C. Mendenhall, Director

\title{
Bulletin 936-N
}

\section{ANTIMONY DEPOSITS OF THE STAMPEDE CREEK AREA KANTISHNA DISTRICT, ALASKA}

\author{
BY \\ DONALD E. WHITE
}

Strategic Minerals Investigations, 1942

(Pages 331-348)

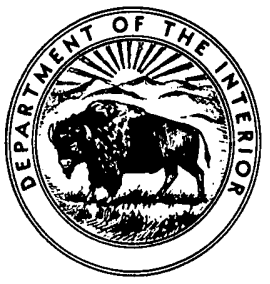

UNITED STATES

GOVERNMENT PRINTING OFFICE

WASHINGTON : 1942

For sale by the Superintendent of Documente, Washington, D. C. . - . . - - Price 25 cents 



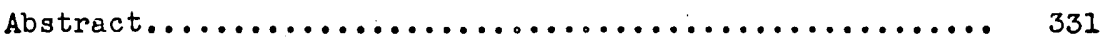

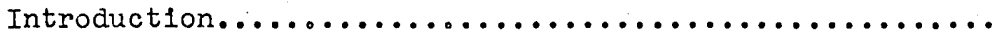

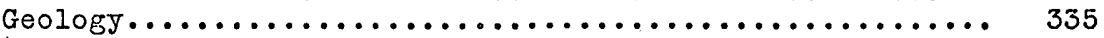

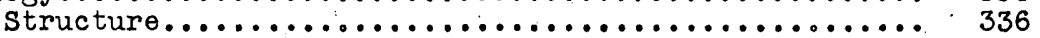

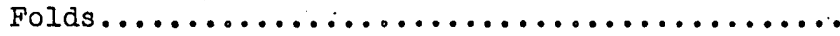

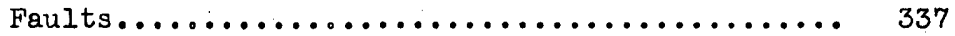

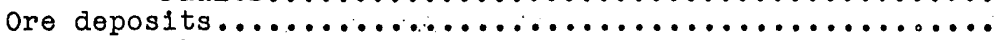

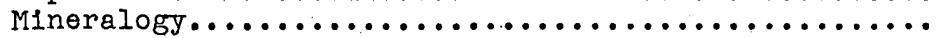

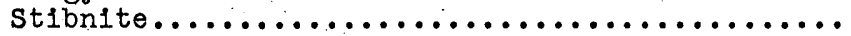

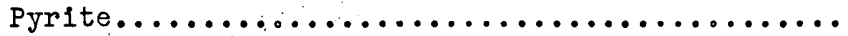

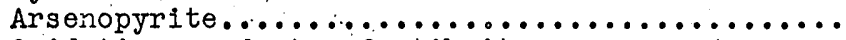

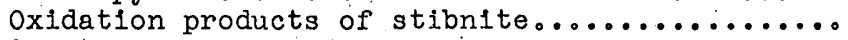

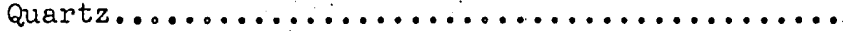

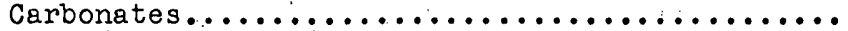

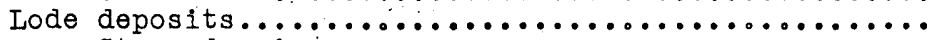

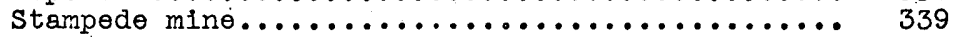

Reserves.

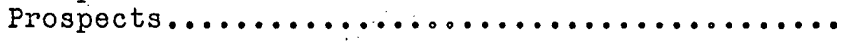

\section{ILLUSTRATIONS}

Page

Plate 49. Geologic map and sections of the Stampede

Creek area, Kantishna district, Alaska... In pocket

50. Geologic map of the underground workings of

the stampede antimony mine............ In pocket

Figure 38. Index map of part of Alaska showing the

location of the stampede Creek area........ 333

39. Geologic map of the surface workings of the

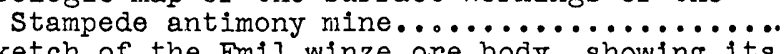

40. Sketch of the Emil winze ore body, showing its buried apex and its decreasing dip with

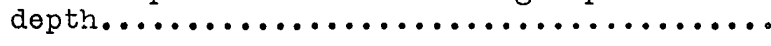





\title{
ANTIMONY DEPOSITS OF THE STAMPEDE CREEK AREA,
}

\author{
KANTISHNA DISTRICT, ALASKA
}

\author{
By Donald E. White
}

\section{ABSTRACT}

The Stampede Creek area lies about 120 miles southwest of Fairbanks, Alaska. It is most readily accessible by air during the summer and by tractor road during the winter.

Since 1936 approximately 2,400 tons of shipping-grade antimony ore and concentrates, containing about 1,300 tons of metallic antimony, have been produced at the stampede mine. The mine was closed down in the spring of 1941, principally because of the high cost of transportation.

The area is underlain largely by metamorphosed rocks of the Birch Creek schist. The schist has been warped and crumpled into many broad, open folds which strike northeast and also plunge to the northeast. The stampede mine is in the schistose quartzite member of the Birch Creek schist.

The antimony occurs principally as the mineral stibnite. It is found in veins, in lenses, and in veinlets in shear zones which are probaily related to the stampede fault, a large northeast-trending fault which cuts a northeast-plunging anticline at a small angle. The vein fractures were formed near the axis of the anticline where the strike of the fault changes from N. $50^{\circ}$ E. to N. $80^{\circ} \mathrm{E}$. The best ore is found at the intersections of the velns with cross faults, and at the acute-angled junction of one of the principal veins with the stampede fault. The veins strike from due north to $\mathrm{N} .80^{\circ} \mathrm{E}$., and dip from $30^{\circ}$ to $75^{\circ}$ to the east and south. The cross faults strike about at right angles to the veins, and dip steeply to the east and north.

The low-grade ore bodies consist of stibnite disseminated in quartz veins as much as 7 feet wide, and of stringer veinlets in schist. Stringer veinlets in zones as much as 30 feet wide form low-grade ore bodies with assay boundaries. The high-grade shipping ore consists of lenses and veins of stibnite up to 5 feet wide, except for one exceptional body which was 26 feet wide. The low-grade mill ore assays from 10 to 20 percent antimony, and the high-grade shipping ore over 50 percent antimony.

The blocked out reserves, as in nearly all antimony deposits, are small. The estimated reserves, including both proved and probable ore, are 70 tons of 50-percent or better ore, 6,000 tons of 10- to 15-percent ore, 1,000 tons of 20-percent ore as loose material below the surface ore body, and 5,000 tons of mill talings which carry about 6 percent of antimony. Two of the ore bodies which have been developed only very slightly may 
contain much more antimony than present estimates indicate. The geological relations are such as to suggest the presence of undiscovered ore bodies.

\section{INTRODUCTION}

The Stampede Creek area is in the east-central part of the Kantishna Hills, a small outlying range north of the Alaska Range in interior Alaska. The Stampede antimony mine, the principal mine in the area, is on Stampede creek, about $2 \frac{1}{2}$ miles above 1 ts junction with the Clearwater River, one of the main tributaries of the Toklat River.

The date of the discovery of the deposit is not known. The first active mining was done in 1915; in response to the very high prices prevailing for antimony at that time. About 150 tons of ore was mined, probably in 1915, but no shipments were made. The property has changed ownership several times. William TayIor was a part owner in 1926. His plans for mining the deposit were disrupted by a sudden decline in the price of antimony. In 1936, Earl R. Pilgrim acquired the claims under lease and option from Taylor and two partners, Drayton and Trundy. Pligrim then. transferred the claims to Morris P. Kirk \& Son, Inc., a subsidlary of the National Lead Co. Active mining was started during the winter of 1936, with Pilgrim in charge of the operations. The first shipments were made in the spring of 1937. Only handpicked ore assaying 52 percent or more of antimony was shipped unt1l 1939, when a 40-ton mill was constructed to concentrate the Low-grade ore.

The mill was in operation during August and September 1939, and from May to september 1940. Difficulties were encountered in obtaining a satisfactory recovery and a high-grade product coarse enough to be acceptable to the smelters of the National Lead Co. The mining of high-grade shipping ore was continued through the winter months of 1940-41 until March, when all operations at the stampede mine were discontinued. The total 
production of ore and concentrates by years is shown in the table on page 334 .

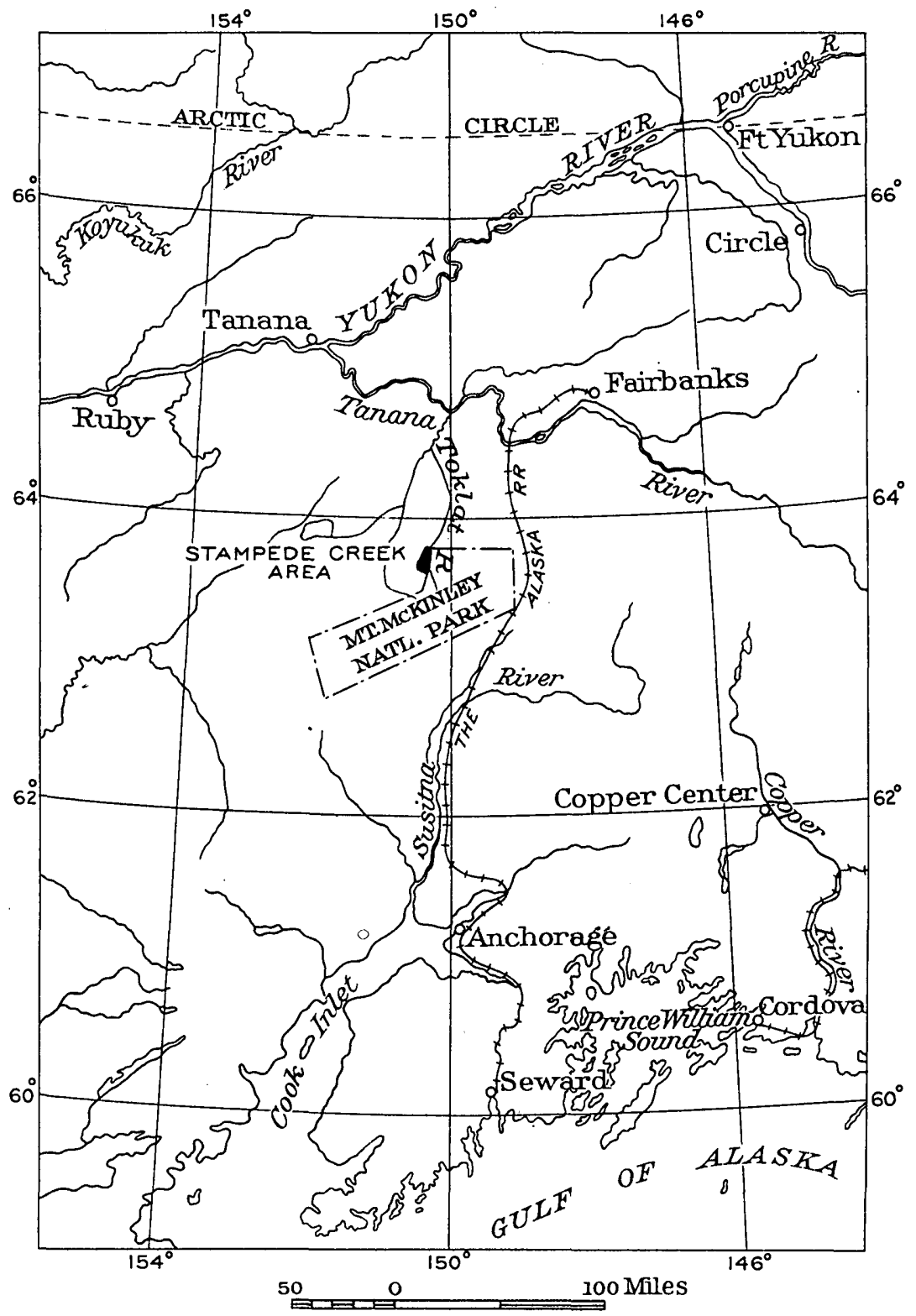

Flgure 38.--Index map of part of Alaska showing the location of the Stampede Creek area.

The high cost of transportation was one of the principal

reasons for closing the mine. The area is most readily accessible by airplane and, during the winter months, by a tractor road 
over the ice and snow from Lignite, a station on the Alaska Railroad, 45 miles east of the stampede mine. The present cost for transportation of ore or concentrates from the mine to Seattle, Wash., is approximately 3 cents per pound of contained antimony calculated on the basis of material containing 52 percent antimony.

Production of antimony ore and concentrates from the stampede mine

\begin{tabular}{|c|c|c|c|c|}
\hline Year & $\begin{array}{l}\text { Ore and } \\
\text { concentrates } \\
\text { (tons) }\end{array}$ & $\begin{array}{c}\text { Antimony } \\
\text { (percent) }\end{array}$ & $\underset{\text { (tons) }}{\text { Antimony }}$ & Value \\
\hline $\begin{array}{l}1937 \ldots \ldots \ldots \ldots \ldots \ldots \\
1938 \ldots \ldots \ldots \ldots \ldots \ldots \\
1939 \ldots \ldots \ldots \ldots \ldots \ldots \ldots \\
1940 \ldots \ldots \ldots \ldots \ldots \ldots \\
1941 \ldots \ldots \ldots \ldots \ldots\end{array}$ & $\begin{array}{l}873.67 \\
426.73 \\
211.51 \\
293.83 \\
582.90\end{array}$ & $\begin{array}{l}55.01 \\
52.00 \\
49.68 \\
52.16 \\
53.47\end{array}$ & $\begin{array}{l}481 \\
222 \\
105 \\
153 \\
312\end{array}$ & $\begin{array}{r}\$ 147,667 \\
54,834 \\
25,956 \\
42,840 \\
87,360\end{array}$ \\
\hline 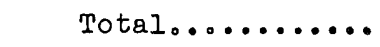 & $2,388.64$ & $\ldots \ldots$ & $1,2^{r} ; 3$ & $\$ 358,657$ \\
\hline
\end{tabular}

1/ The figures for value are based on the average price of antimony for the respective years.

Caterplilar tractors were used to haul the large ore sleds during the winter. The tractor road was not used during the summer months becauise much of the country is low and marshy, and the valleys of several large rivers would have had to be crossed.

Six weeks in the summer of 1941 were spent in mapping approximately 25 square miles surrounding the mine. The area mapped, only part of which is shown in plate 49 , extends along the Clearwater River from its junction with the Toklat River southward to the north fork of Canyon Creek. The area includes all of the drainage basin of Stampede Creek, and parts of the basins of Iittle Moose Creek and the north fork of Canyon Creek. Both geologic and topographic mapping were done by pace and compass traverses controlled by plane-table triangulation. The mine and the surface workings were mapped in detail. 
The author wishes to acknowledge the helpful assistance of W. H. Myers, who was his recorder during the fleld season, and the ald of Earl P1lgrim, manager of the stampede mine, who was placer-mining on Iittle Moose Creek while the Survey party was In the area. Morris P. Kirk \& Son generously permitted access to the mine and use of the camp, and have consented to the publication of figures on production and ore reserves. The writer wishes to thank Lee Swisher and Steve Leposky, placer miners on the upper part of Stampede Creek, for their help and information.

Antimony deposits in the western part of the Kantishna district were first described by Prindle $1 /$ in 1906. The stampede deposit, in the eastern part of the district, was studied in 1916 by Capps, who described the massive body of stibnite which cropped out at the surface. In 1930, after some mining had been done, Moffit examined the antimony deposit in somewhat greater deta1l. Capps, in 1940, summarized the geologic work that has been done at various times in the Kantishna region.

\section{GEOLOGY}

In the area represented by plate 49 , the rocks consist for the most part of gently folded schists of various types, collectively known as the Blrch Creek schist of probable pre-Cambrian age. The Blrch Creek schist in the Stampede Creek area has been divided on the basis of lithology into several units, one of which, the schistose quartzite, is the host rock of the antimony deposits at the stampede mine. The schistose quartzite in the Stampede Creek drainage basin is as much as 200 feet thick, and

\footnotetext{
1/ Prindle, L. M. The Bonnifield and Kantishne regions, Alaska: U. S. GeoI. Survey Bul1. 314, pp. 219-220, 1907.

2/ Capps, S. R., The Kantishna region, Alaska: U. S. Geol. Survey Bull. 687. p. 109, 1919.

2/ Moffit, I. H., The Kont1shna district, Alaska: U. S. Geol. Survey Bul1. 836, pp. 311-312, 1932.

4/ Capps, S. R.. Geology of the Alaska Railrodd region: U. S. Geol. Survey Bull. 907, od. 14-21. 93-130. 1940.
}

$4886830-42-2$ 
is generally a white, tan, or gray micaceous quartzite with some phylite and black slate. It forms ridges on the limbs of the Stampede anticline ard, near the axis of the anticline, is particularly schistose.

Locally, as for example near the head of Little Moose Creak, the older rocks are cut by small basalt dikes, and a flow, largely of basalt, crops out extensively a short distance northeast of the area represented by plate 49. Two altered dikes, essentially of andesitic composftion but too small to be shown on plate 49, are exposed at the stampede mine. At least one of these, shown in figure 39, apparently was intmuded in part along ore structures prior to the introduction of the ore.

The valleys are floored by gravels, and gravel-covered terraces extend along the Clearwater River valley at several levels up to about 300 feet above the river.

\section{Structure}

Folds.-Where bedding can be distinguished, it generally is parallel to the schistosity, but in places the schistosity cuts across such structures as small drag folds. Most of the structural observations were made on planes of schistosity, because the bedding is commonly obscured or destroyed.

The schist has been warped and crumpled into many broad, open folds which strike approximately N. $45^{\circ} \mathrm{E}$. and plunge to the northeast. However, the axis of the major fold in the area, the Stampede anticline, strikes in general about $\mathrm{N} .75^{\circ} \mathrm{E}$, with a range of from N. $55^{\circ} \mathrm{E}$. to S. $85^{\circ} \mathrm{E}$, and plunges to the northeast. Smaller folds are indicated by changes in the strike and dip of the schistosity along ridges or streams. Bedrock on the slopes is generally concealed so that the exact forms and positions of individual folds are difficult to determine. Most of the folds are probably small, and some of them are slightly 
asymetrical, with somewhat steeper dips on the north limbs than on the south.

Drag folds are numerous and possibly earlier than and unrelated to the larger open folds. The drag folds are generally tightly compressed and many of them indicate an overriding from the south and southeast.

Faults.--One major fault and a few minor ones have been mapped, but faults are probably much more common than has been indicated on plate 49. Displacements by fauling are commonly not apparent because outcrops are not abundant, and because the contacts of some of the members of the Birch Creek schist are gradational and poorly defined, and distinctive horizons are absent.

The major fault, here named the stampede fault, has probably controlled the deposition of the antimony ore. The general strike is N. $50^{\circ}$ E., but near the mine it is about N. $80^{\circ} \mathrm{E}$. The dip is known only near the mine, where it is $75^{\circ} \mathrm{SE}$. The fault is normal, but the total displacement is not known although 1t is probably considerable (see sec. B-B', pl. 49)。 In the mine area, and half a mile to the northeast, the fault is marked by blue gouge up to at least 6 feet thick. The fault passes under terrace gravels to the northeast, and was not traced more than

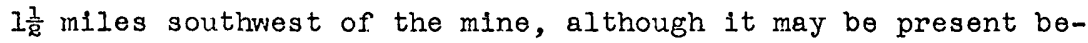
yond that point.

Veins and cross faults within the stampede mine appear to be related to the pronounced change in strike of the stampede fault near the mine area. The veins strike from N. $80^{\circ} \mathrm{E}$. to due north, and dip to the south and east. The cross faults generally strike at about right angles to the associated veins, and generally dip to the east and north at moderate to high angles, although a few dip to the west. Drag folds in the adjacent schist indicate that movement along the veins and cross faults was normal. 
ORE DEPOSITS

Within the Stampede Creek area antimony lodes and gold placers have been mined. The antimony is present principally as stibnite, mainly in the schistose quartzite member of the Birch Creek schist. All of the antimony production has come from the Stampede mine, but three other antimony prospects have been found.

\section{Mineralogy}

Stibnite.--Stibnite $\left(\mathrm{Sb}_{2} \mathrm{~S}_{3}\right)$ is the principal antimony ore mineral in the Stampede Creek area. It is commonly finely granular. Polished sections of the ore indicate an average grain size of about 0.01 millimeter in thickness and about 0.02 millimeter in the other two directions. Most of the crystals are orlented with the long dimensions parallel to the vein walls. A late generation of needlelike stibnite crystals cementing brecciated early stibnite is quantitatively insignificant. The needlelike crystals are commonly several millimeters long. Quartz is the most abundant associated mineral, but pyrite, arsenopyrite, and antimony oxides are also commonly present. Sphalerite was found in one prospect pit. Stibnite was formed later than the other sulfide minerals.

Pyrite.--Pyrite $\left(\mathrm{FeS}_{2}\right)$ is the most common sulfide associated with the stibnite. Small grains are disseminated in stibnite, but are embayed and cut by stibnite veinlets. According to Earl Pilgrim, a sample from the concentrating table of the mill at the stampede mine consisting of approximately 50 percent pyrite assayed 1.71 ounces of gold per ton. However, some of the antimony-poor parts of the veins contain abundant pyrite, but no assays showed more than 0.09 ounce of gold per ton.

\footnotetext{
5/ Personal commication.
} 
Arsenopyrite.--Arsenopyrite (FeAsS) is found as very small crystals, generally disseminated in quartz in the antimony-poor parts of the velns. Very little is associated with stibnite. The age relations between pyrite and arsenopyrite were not determined.

Oxidation products of stibnite.--Kermesite ( $\left.\mathrm{Sb}_{2} \mathrm{~S}_{2} \mathrm{O}\right)$, in veinlets and as coatings on stibnite, is abundant in the stampede mine in many of the accessible subsurface workings, all of which are in permanently frozen ground. It has been observed in the Stampede mine on the Upper Tunnel level, and down to the 50-foot level in the Emil winze, the only place in the mine where the change from partly oxidized ore to unoxidized ore could be observed. The common antimony oxides cervantite $\left(\mathrm{Sb}_{2} \mathrm{O}_{3} \cdot \mathrm{Sb}_{2} \mathrm{O}_{5}\right)$ and stibiconite $\left(\mathrm{Sb}_{2} \mathrm{O}_{3} \cdot \mathrm{Sb}_{2} \mathrm{O}_{5} \cdot \mathrm{nH}_{2} \mathrm{O}\right)$ have been observed only at the surface. Unfortunately, none of the workings were accessible between the surface and the Upper Tunnel level, but accoraing to Pilgrim the change from the antimony oxides to kermesite coincides approximately with the upper surface of permanently frozen ground.

Quartz--Quartz is the principal gangue mineral associated with the stibnite. Small, doubly terminated crystals are disseminated through the high-grade stibnite, and were probably deposited contemporaneously. The crystals show no fracturing or straining.

Carbonates.--Calcite, and possibly dolomite, are very minor constituents of the stibnite-quartz veins.

\section{Lode deposits}

Stampede mine

The stampede mine is on the south side of Stampede Creek about $2 \frac{1}{2}$ miles west of its junction with the Clearwater River.

6) Personal commanication. 


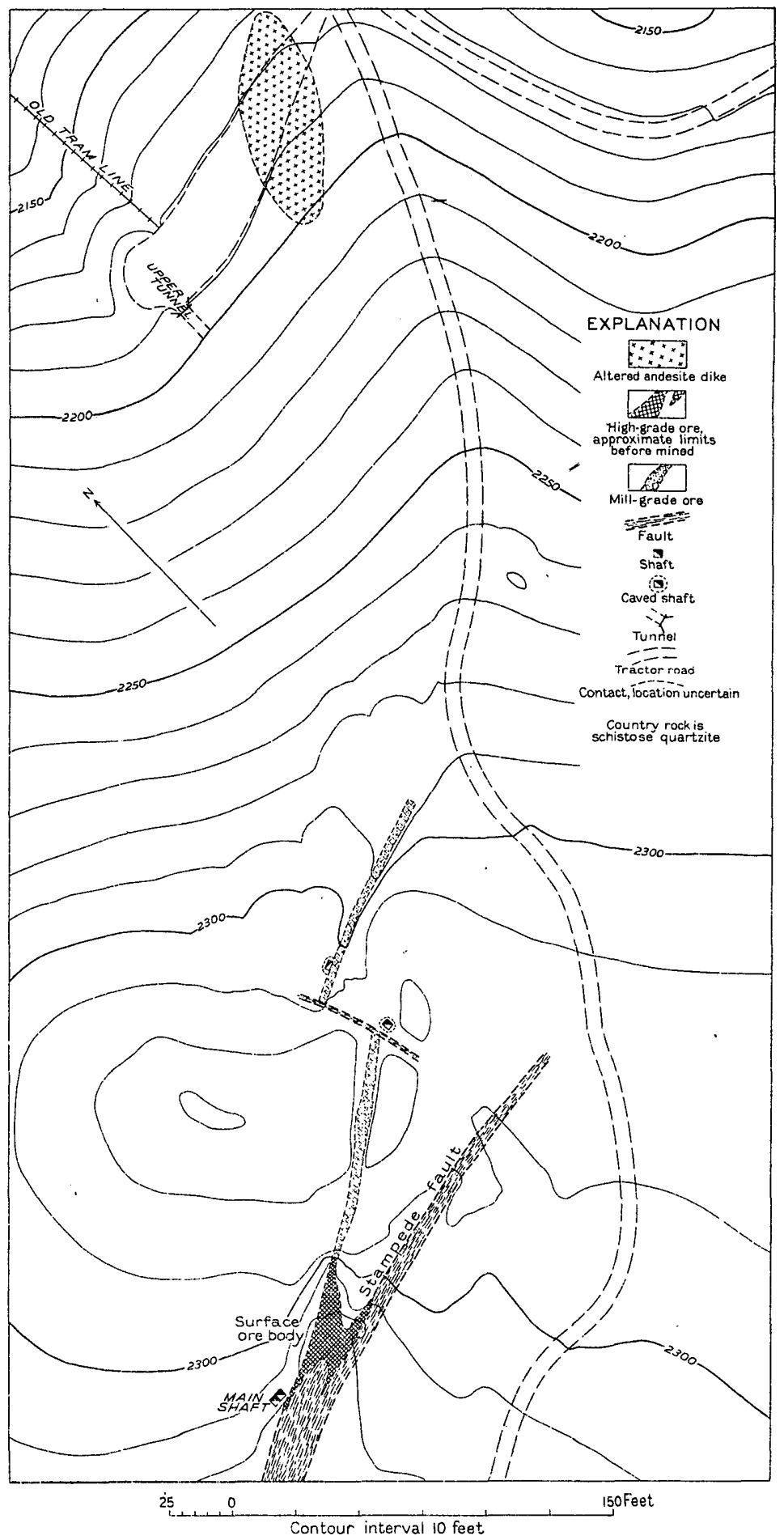

Figure 39.--Geologic map of the surface workings of the Stampede antimony mine. 
The mine was closed down early in 1941 because of the low price of antimony, the high cost of transportation, and the low mill recovery.

The stampede mine contains several velns, or series of veins, one of which follows a low-angle offshoot of the stampede fault. The veins strike from N. $80^{\circ} \mathrm{E}$. to due north, and dip $30^{\circ}$ to $80^{\circ}$ E. The veins are commonly wider and higher in grade near premineral cross faults, which are tight and only slightly minerallzed and which cut the veins approximately at right angles. The cross faults generally dip at moderate to steep angles to the east and north. The stmuctures within the mine are probably related to the "bend" in the stampede fault where the fault strikes N. $80^{\circ}$ E., differing locally from the average of N. $50^{\circ}$ E. Several of the ore bodies have been found in the veins Immediately east and north of cross faults; that is, on their hanging-wall sides. However, the largest ore body, called the Surface ore body, lay between the stampede fault and a vein that branches from it.

The stibnite in the Stampede mine occupies veins and kidneys with fairly definite walls, and from a fraction of a foot to 26 feet wide. Stibnite is also present in stringers and veinlets in brecclated shear zones. 10 to 30 feet wide in schist. The veinlets are commonly almost pure stibnite and in places are abundant enough so that the shear zones constitute mill ore, assaying 10 percent or more of antimony.

The percentage of minor constituents in the ore is not known. The average concentrates, according to Mr. Morris P. Kirk, contain approximately 55.5 percent of antimony, 0.40 percent of lead, 0.50 percent of arsenic, and only traces of copper and zinc. A composite sample taken by the author from three sacks of mill concentrates which were left at the mine, contalned 59.80 
percent of antimony, 0.62 percent of arsenic, 0.03 ounce of gold and 0.41 ounce of silver to the ton, and traces of copper, lead, and zinc.

The veins have a wide range of antimony content. Several shoots of high-grade stibnite ore, with antimony contents up to 69 percent, have been opened by mining. Around some shoots is a border of quartz and included schist fragments. Also, in places the vein fliling contains little or no stibnite.

The Surface ore body which consisted of almost pure stibnite at the surface, passes downward and in both directions along the strike of the vein into a breccla zone of vein quartz, included schist fragments, pyrite, and negligible amounts of stibnite. The veln has not been explored below the Upper Tunnel level which is about 90 feet below the outcrop of the ore body. Earl Pllgrim has described this ore body, which had beer largely mined out before the current studies were made, as an irregular mass with a maximum width of 26 feet. At the surface a high-grade zone of nearly pure stibnite assaying over 60 percent of antimony lay between the two walls, and extended 25 feet below the surface, where quartz and schist became prominent const1tuents. The central part of the ore body was mined down to a depth of 45 feet where the ore contained about 10 to 15 percent of antimony. A band of high-grade stibnite on each wall persisted to greater depths. At the surface, In both directions along the strike of the high-grade ore body, which was about 65 feet in length, the ore became increasingly intermixed with quartz and schist.

The Emil winze ore body is a definite vein, with 1 to 7 feet of medium- and high-grade ore on the Upper Tunnel and 50-foot levels, where the dip is $70^{\circ} \mathrm{SE}$. Below a position a little above the 50-foot level, the vein splits with flat offshoots in

8f Personal communication. 


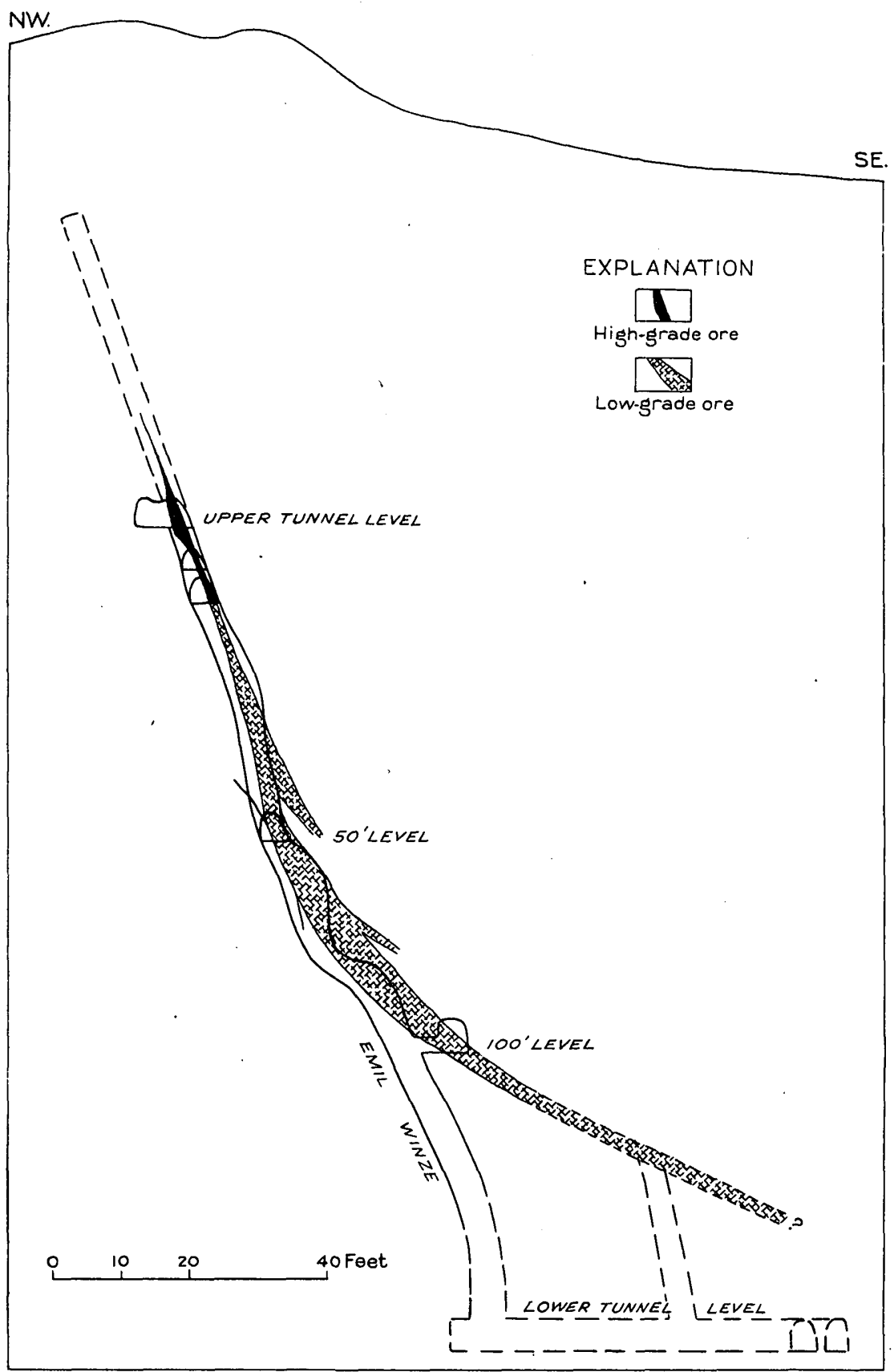

Figure 40.--Sketch of the lintl wine ore body, showing 1 ts burled apex and its decreasing dip with depth. 
the hangling wall, and on the 100-foot level, about 40 feet northeast of the plane of the section represented by figure 40 , the vein is a brecclated zone of schist with a width of 20 feet or more, a dip of $30^{\circ}$ to $35^{\circ}$, and an antimony content of 10 to 15 percent. The high-grade parts of this vein are in general in the steeply dipping parts. The best ore was mined at and just below the Upper Tunnel level, south of the Emil winze, where the vein consisted of 3 feet of high-grade ore, terminated on the south by a pre-inineral cross fault.

A little ore has been mined above the Upper Tunnel level, but the vein decreased in width upward. No ore was found more than 20 feet above the Upper Tunnel level in No. 1 raise, and the vein does not crop out at the surface.

Much of the ore from the Emil winze ore body was mined between the Upper Tunnel and the 50-foot levels. The ore between the two inclined raises on the vein below the 50-foot level is largely mined out. The ore under the northern raise has not been mined between the 50-foot level and the 100-foot level, and constitutes a significant reserve. Little is known about the vein below the 100-foot level. According to Pilgrim, the vein In the inaccessible level between the Lower Tunnel level and the 100-foot level dips $30^{\circ} \mathrm{SE}$, is 20 to 30 feet wide, and contains 10 percent of antimony. The ore above and below this inaccessible level constitutes the probable reserves in the ore body.

The Emil winze ore body has not been found on the Lower Tunnel level, unless its lower extension is the Mooney ore body. If the Emil winze vein maintains a dip of $30^{\circ}$, it should lie southeast of the present workings at the elevation of the Lower Tunnel.

The Mooney ore body strikes N. $65^{\circ} \mathrm{E}$. and dips $48^{\circ} \mathrm{SE}$. The vein has been explored only by a 40-foot drift which was stopped In ore, and by a 15-foot raise, which was also stopped in ore. Therefore, the limits of the ore body are unknown in all direc- 
tions except to the west, where the ore is terminated by two pre-mineral cross faults. The vein is at least 6 feet wide, and consists of brecciated schist contalning veinlets of stibnite. One persistent vein of almost pure stibnite, about 2 inches wide, extends for the explored length of the vein.

The Nesse winze ore body on the Upper Tunnel level consists largely of vein quartz and brecclated schist containing 10 percent or less of antimony. Six feet down in the Nesse winze, stibnite is a prominent constituent of the vein. The winze has been sunk to 20 feet below the level, where the vein consists of 1 foot of almost pure stibnite. The raise on this vein above the Upper Tunnel level failed to reveal ore.

Past exploration has been guided by the belief that the ore bodies are on one, or possibly two veins offset by pre-mineral cross faults. Another possible interpretation, apparently consistent with the author's observations, is that the veins occupy numerous fractures and cross faults which together form a complex system. According to the second interpretation much ground favorable for prospecting still remains, particularly between the Stampede fault and the present mine workings.

Minor post-mineral movement is evident in parts of the mine. In several places movement within the vein has polished and slickensided quartz and stibnite. In other places in the mine, massive, high-grade stibnite ore has been brecciated and partially cemented by later stibnite which forms pockets and clus. ters of fine needle crystals within the fractures. However, little or no post-mineral movement has been observed along the cross faults.

\section{Prospects}

Small veins of stibnite and antimony oxides have been found In other parts of the Stampede Creek area. Quartz containing some stibnite and a little sphalerite was found in a caved 
prospect hole on Stampede Creek several hundred yards upstream from the mine buildings.

A small northward-striking fault on the ridge northeast of the mine contains stibnite. The vein has been prospected by a wide trench, which revealed only a little mineralization. Some stibnite float was found just north of the same ridge in the drainage basin of Little Moose Creek.

Many other stibnite veins and showings have been found in adjacent parts of the Kantishna Hills, particularly in the western part of the district, but these are not considered in the present report.

\section{RESERVES}

The blocked out reserves at the stampede mine are small, as is true of nearly all antimony deposits. Exact figures on the size and grade of the different ore bodies could not be obtained. of the total production from the mine, which has been 1,273 tons of metallic antimony, more than half has come from the Surface ore body in the form of high-grade shipping ore. The remainder has come from the Emil winze ore body, except for an unknown amount from the near-surface workings east of the Surface ore body, and minor amounts from the Nesse winze ore body on the Upper Tunnel level, and the Mooney ore body on the Lower Tunnel level.

The proved and probable reserves in the Enil winze and Surface ore bodies cannot be closely estimated because some of the critical workings are inaccessible. Development work had just been started on the Nesse winze and Mooney ore bodies when the

- mine was closed down, and, although these may prove to be of considerable extent, their size and grade are not known.

Approximately 700 tons of metallic antimony has been recovered from the surface ore body, according to Pilgrim. $\stackrel{9 /}{ }$ The

2/ PIIrim, I. R., personal communication. 
total tonnage of ore is not known, but most of it contained from 50 to 68 percent antimony, although some contained only 15 percent. Some ore of a lower grade than 15 percent still remains in the body.

The Emil winze ore body has probably produced about 500 tons of metallic antimony. Some high-grade ore remains in the body as well as a considerable amount of ore that may contain about 15 percent of antimony. Probable reserves, according to Pilgrim, are 4,000 tons of 10-percent ore. This estimate appears reasonable but it could not be checked because part of the workings was inaccessible.

The very slight development of the Nesse winze ore body indicates the presence of at least a few tons of ore which contains 50 percent or more of antimony. Further development of this body may greatly increase the reserve estimate for the body.

The Mooney ore body, like the Nesse winze body, is only partly developed, and data for estimating grade and reserves are very scanty. Most of the ore so far exposed in the body is of milling grade.

The alluvium downhill from the Surface ore body contains at least 1,000 tons of oxidized ore assaying 20 percent of antimony, according to Pligrim. The abundant high-grade float on the surface and in trenches support this estimate; however, because of insufficient data as to quantity, quality, and suitability for milling, this material is classed as probable and not as proved ore.

The 5,000 tons of mill tailings constitute a proved reserve of inferior quality. If the tallings were retreated, the product would be much finer in size than the National Lead Co. cares to handle in its smelters. An admittedly unreliable grab sample from the tailings pile contained 7.45 percent of antimony, but

10/ P1lgrim, E. R., personal communication. 
the computed average antimony content of the whole pile is said to be about 6 percent.

Very conservatively estimated reserves of the stampede mine, including both proved and probable ore, are summarized in the following table:

Estimated antimony reserves of the stampede mine

\begin{tabular}{|c|c|c|c|}
\hline & $\begin{array}{l}\text { Ore } \\
\text { (tons) }\end{array}$ & $\begin{array}{l}\text { Antimony } \\
(\text { percent })\end{array}$ & $\begin{array}{c}\text { Antimony } \\
\text { (tons) }\end{array}$ \\
\hline 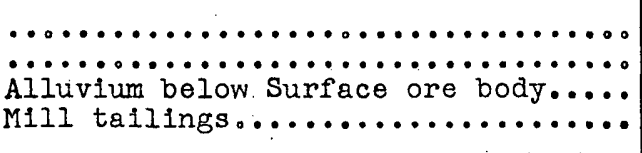 & $\begin{array}{r}70 \\
6,000 \\
1,000 \\
5,000\end{array}$ & $\begin{array}{r}50 \\
10-15 \\
20 \\
6\end{array}$ & $\begin{array}{r}35 \\
630 \\
200 \\
300\end{array}$ \\
\hline 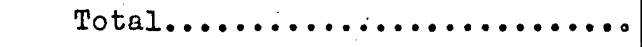 & 12,070 & $\ldots \ldots$ & 1,165 \\
\hline
\end{tabular}

The geological relations suggest that the mine contains additional undiscovered ore bodies between the present workings and the stampede fault, which may well equal the total of past production plus partly or fully blocked-out reserves known at the present time. However, the absence of any exploration provIng or more than suggesting these additional reserves should be stressed.

In spite of the difficulties encountered by the operator in attempting to obtain a satisfactory recovery of material coarse enough to be acceptable for the smelters of the National Lead Co., it seems likely that the Stampede mine $1 \mathrm{~s}^{\circ}$ capable of contributing very considerably to the Nation's supply of antimony. 